\title{
Effect of Dates of Sowing and Fertility Levels on Yield Attributes and Yield of Baby Corn (Zea mays L.) under Temperate Conditions
}

\author{
Tanveer Ahmad Ahngar ${ }^{1 *}$, Zahida Rashid ${ }^{2}$, Raies A. Bhat ${ }^{1}$, A. A. Saad ${ }^{1}$, \\ M. Anwar Bhat ${ }^{1}$, Taussef Ahmad Bhat ${ }^{1}$, Suhail Inamullah ${ }^{3}$, \\ Shabeena Majid ${ }^{2}$, Seerat Jan $^{1}$ and Aijaz Nazir ${ }^{1}$ \\ ${ }^{1}$ Division of Agronomy, ${ }^{2}$ Dryland Agriculture Research Station, Sher- $e$ - Kashmir University \\ of Agricultural Sciences and Technology of Kashmir, Jammu and Kashmir, India \\ ${ }^{3}$ Directorate of Agriculture, Srinagar, Jammu and Kashmir, India, India \\ *Corresponding author
}

\begin{tabular}{l} 
K e y w o r d s \\
$\begin{array}{l}\text { Baby corn, Sowing } \\
\text { dates, Fertility } \\
\text { levels, Yield } \\
\text { attributes, Yield }\end{array}$ \\
Article Info \\
$\begin{array}{l}\text { Accepted: } \\
\text { 22 July } 2020 \\
\text { Available Online: } \\
\text { 10 August } 2020\end{array}$ \\
\hline
\end{tabular}

dates, Fertility

levels, Yield

attributes, Yield

\section{Article Info}

Accepted:

Available Online:

10 August 2020

\section{A B S T R A C T}

To study the effect of dates of sowing and fertility levels on yield attributes and yield of baby corn (Zea mays L.) under temperate conditions, an experiment was conducted at Crop Research Farm of Division of Agronomy, Faculty of Agriculture, Sher-e-Kashmir University of Agricultural Sciences and Technology of Kashmir, Wadura during Kharif 2018. The experiment comprised of two factors with four sowing dates viz., $18^{\text {th }}$ SMW ( $30^{\text {th }}$ April $-6^{\text {th }}$ May), $21^{\text {st }}$ SMW ( $21^{\text {st }}$ May $-27^{\text {th }}$ May), $24^{\text {th }}$ SMW ( $11^{\text {th }}$ June $-17^{\text {th }}$ June $)$ and $27^{\text {th }}$ SMW ( $2^{\text {nd }}$ July $-8^{\text {th }}$ July) as main plot treatments and four fertility levels viz., unfertilized control $\left(\mathrm{F}_{0}\right), 100: 50: 25 \mathrm{~N}: \mathrm{P}_{2} \mathrm{O}_{5}: \mathrm{K}_{2} \mathrm{O} \mathrm{kg} \mathrm{ha}{ }^{-1}\left(\mathrm{~F}_{1}\right), 120: 60: 30 \mathrm{~N}: \mathrm{P}_{2} \mathrm{O}_{5}: \mathrm{K}_{2} \mathrm{O} \mathrm{kg}$ $\mathrm{ha}^{-1}\left(\mathrm{~F}_{2}\right)$ and 140: 70: $35 \mathrm{~N}: \mathrm{P}_{2} \mathrm{O}_{5}: \mathrm{K}_{2} \mathrm{O} \mathrm{kg} \mathrm{ha}{ }^{-1}\left(\mathrm{~F}_{3}\right)$ as sub-plot treatments laid out in split plot design with three replications. The results indicated that baby corn sown in $18^{\text {th }}$ SMW $\left(30^{\text {th }}\right.$ April $-6^{\text {th }}$ May) recorded significantly higher yield attributes viz., Number of baby corn per plant, baby corn girth with and without husk, weight of single baby corn with and without husk and baby corn yield and green fodder yield compared to other sowing dates and $27^{\text {th }}$ SMW sowing date $\left(2^{\text {nd }}\right.$ July $-8^{\text {th }}$ July) recorded significantly lower yield attributes and yield of baby corn, however baby corn length with and without husk was not influenced by different sowing dates. Among different fertility levels, 140:70:35 N: $\mathrm{P}_{2} \mathrm{O}_{5}$ : $\mathrm{K}_{2} \mathrm{O} \mathrm{kg} \mathrm{ha}{ }^{-1}\left(\mathrm{~F}_{3}\right)$ fertility level recorded significantly higher yield attributes viz., Number of baby corn per plant, baby corn girth with and without husk, weight of single baby corn with and without husk and baby corn length with and without husk and baby corn yield and green fodder yield compared to other fertility levels whereas unfertilized control $\left(\mathrm{F}_{0}\right)$ recorded significantly lower yield attributes and yield.

\section{Introduction}

Maize (Zea mays L.) is one of the most important coarse cereals which are widely distributed around the globe. It is an important staple food in many countries and is also used as an animal feed. In India, it is an important crop not only in terms of acreage 
but also in context to its versatility for adoption under wide range of agro-climatic conditions. Globally maize is cultivated over an area of 179.09 million hectare with a production of 967 million tonnes and productivity is 5.4 tonnes $\mathrm{ha}^{-1}$ (Anonymous, 2018). In India maize is cultivated over 9.2 million hectare area with a production of 28.72 million tonnes and productivity is 3.11 tonnes $\mathrm{ha}^{-1}$ (Anonymous, 2018). The predominant maize growing states in India are Andhra Pradesh, Karnataka, Tamil Nadu and Rajasthan. Apart from these states it is also grown in Jammu and Kashmir. In Jammu and Kashmir maize is grown on an area of 3.10 lakh hectares with production of 5.27 lakh tonnes and productivity is 1.7 tonnes $\mathrm{ha}^{-1}$ (Anonymous, 2018).

Special purpose corns viz., baby corn, sweet corn, pop corn etc. assume tremendous market potential not only in India but in the international market as well. For value addition and diversification of maize as well as the growth of the food processing industry, growing maize for vegetable which is known as baby corn, is contemplated. Baby corn is dehusked maize ear harvested young especially when the silk have either not emerged or just emerged and no fertilization has taken place or we can say the shank with unpollinated silk is baby corn. Baby corn is light yellow in colour with regular row arrangement having 10 to $12 \mathrm{~cm}$ length and 1 to $1.5 \mathrm{~cm}$ diameter are preferred in the market (Golada et al., 2013).

Baby corn is a delicious vegetable and is consumed as a natural food. It has immense potential both for internal consumption as well as for export. It can be eaten raw as well as included in diet in many of ways as chutneys, vegetables, salads, pickles, etc. It is very much nutritive and its nutritional quality is at par or even higher to some of the vegetables viz., cabbage, tomato, French bean, cauliflower, spinach, lady finger, radish etc. It contains $81.97 \%$ total carbohydrates, 10.04 $\mathrm{g} / 100 \mathrm{~g}$ crude protein, $4.43 \mathrm{~g} / 100 \mathrm{~g}$ crude fiber, $1.34 \mathrm{~g} / 100 \mathrm{~g}$ ash, $0.14 \mathrm{~g} / 100 \mathrm{~g}$ soluble sugars, 375.67 calories energy/100g, $17.76 \mathrm{mg} / 100 \mathrm{~g}$ calcium, $197.89 \mathrm{mg} / 100 \mathrm{~g}$ phosphorus and $2.74 \mathrm{mg} / 100 \mathrm{~g}$ iron (Kawatra and Seghal, 2007). In addition to its nutritive advantage, it is also free from residual effect of pesticides as it is harvested at immature stage within a week of tassel emergence and the cob is wrapped up tightly within the husk and well protected from insects and pests (Kumar and Thakur, 2004). Besides baby corn, green fodder obtained can be used as feed to livestock and the farmers can save their land used for green fodder cultivation. The short duration of the crop enables it to escape from many climatic hazards expected to occur in the later part of the season. There is enormous scope of cultivating maize as baby corn to improve economic status of poor maize growers and has a potential to generate employment opportunities in the rural areas as well.

It is well established that the yield attributes and yield could be enhanced through addition of various growth inputs viz., irrigation, improved varieties, sowing time, plant population and balanced use of fertilizers. Among the various inputs sowing date and fertilization plays a vital role. Sowing date is one of the most important factors influencing the performances of the crop as it is important for better utilization of available moisture and nutrients supplied to the crop. Baby corn is a highly perishable vegetable and has a very short shelf life. Due to this reason baby corn is consumed within a short period. Therefore to extend its availability for a few months staggered sowing can be the alternate strategy. Through staggered sowing multiple crops of baby corn can be raised in a season and with good quality green fodder giving good profit per unit area per unit time. 
Fertilization plays a significant role in increasing crop production and for plant development and yield formation, the presence of nutrient elements viz., nitrogen, phosphorus and potassium in balanced from is essential (Mahmood et al., 1999). Among various nutrients provided to plants, nitrogen is a major and limiting nutrient, associated with vigorous plant growth, deep green colour of leaves and yield of the crop. Nitrogen is considered as most important nutrient for the crop to activate the metabolic activity within the plant and for transformation of energy, chlorophyll and protein synthesis. It governs better utilization of phosphorus, potassium and other nutrient elements. Phosphorous is also an essential plant nutrient. It is involved in cell division, root development, protein synthesis and is associated with a wide range of plant processes viz., photosynthesis, utilization of carbohydrates and growth and development. It is constituent of ADP and ATP, the most important substance in the life processes. Potassium is another essential plant nutrient which plays a significant role in various processes including protein synthesis, stomatal movement, enzyme activation, energy transfer, phloem transport and stress resistance.

The research on impacts of dates of sowing and fertility levels on yield attributes and yield of baby corn has been lacking in this region. In view of above facts the study entitled, "Effect of dates of sowing and fertility levels on yield attributes and yield of baby corn (Zea mays L.) under temperate conditions" was carried out.

\section{Materials and Methods}

The experiment was conducted at Crop Research Farm of Division of Agronomy, Faculty of Agriculture, Sher-e-Kashmir University of Agricultural Sciences \& Technology of Kashmir, Wadura Sopore during Kharif, 2018. The site is situated between $34^{\circ} 21^{\prime} \mathrm{N}$ and $74^{\circ} 23^{\prime} \mathrm{E}$ at an altitude of 1590 meters above mean sea level. Climatically the experimental site is in mid to high altitude temperate zone characterized by hot summers and very cold winters. The average annual precipitation is $812 \mathrm{~mm}$ (average over past twenty years) and more than $80 \%$ of precipitation is received from western disturbances. The soil of the experimental plot was clay loam in texture, medium in organic carbon, medium in available nitrogen, available phosphorus and available potassium with normal electrical conductivity and neutral $\mathrm{pH}$.

The experiment comprised of two factors with four sowing dates viz., $18^{\text {th }}$ SMW (30 ${ }^{\text {th }}$ April $6^{\text {th }}$ May), $21^{\text {st }}$ SMW (21 $1^{\text {st }}$ May $-27^{\text {th }}$ May), $24^{\text {th }}$ SMW $\left(11^{\text {th }}\right.$ June $-17^{\text {th }}$ June $)$ and $27^{\text {th }}$ SMW $\left(2^{\text {nd }}\right.$ July $-8^{\text {th }}$ July) as main plot treatments and four fertility levels viz., unfertilized control $\left(\mathrm{F}_{0}\right)$, 100:50:25 N: $\mathrm{P}_{2} \mathrm{O}_{5}$ : $\mathrm{K}_{2} \mathrm{O}$ kg ha ${ }^{-1}\left(\mathrm{~F}_{1}\right)$, 120: 60: $30 \mathrm{~N}: \mathrm{P}_{2} \mathrm{O}_{5}: \mathrm{K}_{2} \mathrm{O} \mathrm{kg}$ $\mathrm{ha}^{-1}\left(\mathrm{~F}_{2}\right)$ and 140: 70: $35 \mathrm{~N}: \mathrm{P}_{2} \mathrm{O}_{5}: \mathrm{K}_{2} \mathrm{O} \mathrm{kg} \mathrm{ha}{ }^{-1}$ $\left(\mathrm{F}_{3}\right)$ as sub-plot treatments laid out in split plot design with three replications. Total numbers of treatment combinations were 16 and the total numbers of treatment plots were 48. The gross plot size of each subplot was $14 \mathrm{~m}^{2}$ and the net plot size of each subplot was $9 \mathrm{~m}^{2}$.

Total number of baby corn of 10 randomly marked plants in each plot were counted before picking and then averaged as number of baby corn per plant. The length of 10 randomly selected cobs from the harvested lot of each plot was measured with and without husk from tip to bottom of the cob with meter scale and the mean length per cob with and without husk was determined in centimeters (cm). The 10 randomly selected cobs which were used for measuring baby corn length were also used for measurement of baby corn girth. The diameter of cobs with and without 
husk was measured with the help of vernier caliper at three places i.e., at the base, the centre and the pointed end of the cob and then the average diameter for individual cobs was worked out. From diameter the girth (circumference) of each individual cob was calculated by using the following formula and subsequently averaged as young cob girth with and without husk.

$2 \times \pi \times r$

Where, $r=\frac{\text { diameter }}{2}, \quad \pi=\frac{22}{7}$ or 3.14

The young cobs used for measurement of girth were weighed with and without husk and the weight was averaged as weight of baby corn with and without husk. It was expressed in grams per cob. The cumulative weight of young cobs with and without husk from each net plot in all the pickings was taken in kilogram and then expressed as $\mathrm{q} \mathrm{ha}^{-1}$. The green fodder harvested from each net plot after completion of pickings was tied in bundles and weighed in $\mathrm{kg} \mathrm{plot}^{-1}$. The weight was converted to $\mathrm{q} \mathrm{ha} \mathrm{h}^{-1}$. Husk obtained was also included in fodder yield.

\section{Results and Discussion}

\section{Effect of sowing dates}

\section{Yield attributes}

Results revealed that sowing dates did not show any significant difference in baby corn length with and without husk (Table 1). However, number of baby corn per plant, baby corn girth with and without husk $(\mathrm{cm})$ and weight of singe baby corn with and without husk (g) were significantly influenced by sowing dates (Table 1). $18^{\text {th }}$ SMW sowing date $\left(S_{1}\right)$ recorded significantly higher number of baby corn per plant (2.32), baby corn girth with husk $(4.55 \mathrm{~cm})$ and without husk
$(3.01 \mathrm{~cm})$ and weight of single baby corn with husk (31.69 g) and without husk (10.06 g) compared to other sowing dates, whereas late sowing date $27^{\text {th }}$ SMW $\left(\mathrm{S}_{4}\right)$ recorded significantly lowest number of baby corn per plant (1.85), baby corn girth with husk (3.09 $\mathrm{cm})$ and without husk $(1.86 \mathrm{~cm})$ and weight of single baby corn with husk (26.28 g) and without husk ( $8.33 \mathrm{~g})$. Significant increase in yield attributes in early sowing date may be attributed to the fact that the longer time period available for the early sown crop enabled it to utilize available growth resources (light, nutrients, moisture, etc.) to synthesize and partition more assimilates to various sinks for better vegetative growth, leading to the production of higher yield components than the late sown crops. Arash et al., (2011), Khan et al., (2002) reported similar results. The results of Jaliya et al., (2008) also support the findings.

\section{Yield}

Data indicated that sowing dates had a significant effect on baby corn and green fodder yield. A perusal of data in Table 2 indicated that baby corn sown in $18^{\text {th }} \mathrm{SMW}$ $\left(\mathrm{S}_{1}\right)$ recorded significantly higher baby corn yield with husk (69.73 $\left.\mathrm{qha}^{-1}\right)$ and without husk (19.88 $\mathrm{qha}^{-1}$ ) and green fodder yield( $358.01 \mathrm{qha}^{-1}$ ) compared to other sowing dates. However, lowest baby corn yield with husk (48.60 $\mathrm{qha}^{-1}$ ) and without husk (14.50 $\mathrm{qha}^{-1}$ ) and green fodder yield (298.69 $\left.\mathrm{qha}^{-1}\right)$ were recorded with $27^{\text {th }}$ SMW $\left(\mathrm{S}_{4}\right)$ sowing date (Table 2). The probable reason for significant lower baby corn yield and green fodder yield in late sown crop might be the shorter time period available for utilization of available growth resources (light, nutrients, moisture etc.) which resulted in poor dry matter accumulation and also decreased the production and partitioning of assimilates to various sinks, leading to a decline of yield contributing components and yield than early 
sown crop. The findings of Tamadon (2000) also revealed that timely sowing corn resulted in higher grain and fodder yield. The results are also in confirmation with the findings of Mokhtarpour et al., (2013) and Shirkhani et al., (2012).

Table.1 Effect of dates of sowing and fertility levels on yield attributes of baby corn

\begin{tabular}{|c|c|c|c|c|c|c|c|}
\hline \multirow[t]{2}{*}{ Treatments } & \multirow{2}{*}{$\begin{array}{l}\text { No. of } \\
\text { baby corn } \\
\text { per plant }\end{array}$} & \multicolumn{2}{|c|}{$\begin{array}{l}\text { Avg. girth of baby } \\
\text { corn }(\mathrm{cm})\end{array}$} & \multicolumn{2}{|c|}{$\begin{array}{l}\text { Avg. length of baby } \\
\text { corn (cm) }\end{array}$} & \multicolumn{2}{|c|}{$\begin{array}{l}\text { Avg. weight of single } \\
\text { baby corn (g) }\end{array}$} \\
\hline & & $\begin{array}{l}\text { With } \\
\text { husk }\end{array}$ & $\begin{array}{l}\text { Without } \\
\text { husk }\end{array}$ & $\begin{array}{l}\text { With } \\
\text { husk }\end{array}$ & $\begin{array}{c}\text { Without } \\
\text { husk }\end{array}$ & $\begin{array}{l}\text { With } \\
\text { husk }\end{array}$ & $\begin{array}{l}\text { Without } \\
\text { husk }\end{array}$ \\
\hline \multicolumn{8}{|l|}{ MAIN PLOT } \\
\hline \multicolumn{8}{|l|}{ Dates of sowing } \\
\hline $\begin{array}{l}1^{\text {th }} \text { SMW } \\
\left(\mathbf{S}_{1}\right)\end{array}$ & 2.32 & 4.55 & 3.01 & 15.47 & 10.14 & 31.69 & 10.06 \\
\hline $\begin{array}{l}21^{\text {st }} \text { SMW } \\
\left(\mathbf{S}_{2}\right)\end{array}$ & 2.21 & 4.36 & 2.85 & 15.45 & 10.10 & 30.00 & 9.38 \\
\hline $\begin{array}{l}24^{\text {th }} \text { SMW } \\
\left(\mathbf{S}_{3}\right)\end{array}$ & 2.05 & 3.76 & 2.37 & 15.40 & 10.06 & 28.76 & 8.61 \\
\hline $\begin{array}{l}27^{\text {th }} \text { SMW } \\
\left(\mathbf{S}_{4}\right)\end{array}$ & 1.85 & 3.09 & 1.86 & 15.40 & 10.03 & 26.28 & 8.33 \\
\hline SEm \pm & 0.03 & 0.04 & 0.04 & 0.09 & 0.10 & 0.48 & 0.17 \\
\hline$C D(p \leq 0.05)$ & 0.10 & 0.15 & 0.14 & N.S. & N.S. & 1.67 & 0.59 \\
\hline \multicolumn{8}{|l|}{ SUB PLOT } \\
\hline \multicolumn{8}{|l|}{$\begin{array}{l}\text { Fertility levels } \\
\left(\mathrm{N}: \mathrm{P}_{2} \mathrm{O}_{5}: \mathrm{K}_{2} \mathrm{O} \mathrm{kg} \mathrm{ha}{ }^{-1}\right)\end{array}$} \\
\hline $\begin{array}{l}\text { Unfertilized control } \\
\left(\mathbf{F}_{0}\right)\end{array}$ & 1.72 & 2.95 & 1.89 & 12.41 & 7.09 & 23.88 & 7.28 \\
\hline $\begin{array}{l}\text { 100:50:25 } \\
\left(F_{1}\right)\end{array}$ & 1.97 & 3.83 & 2.49 & 15.12 & 9.23 & 27.83 & 8.56 \\
\hline $\begin{array}{l}120: 60: 30 \\
\left(F_{2}\right)\end{array}$ & 2.27 & 4.41 & 2.77 & 16.89 & 11.41 & 31.52 & 9.94 \\
\hline $\begin{array}{l}\text { 140:70:35 } \\
\left(F_{3}\right)\end{array}$ & 2.46 & 4.57 & 2.93 & 17.30 & 12.60 & 33.50 & 10.61 \\
\hline SEm \pm & 0.05 & 0.03 & 0.04 & 0.29 & 0.13 & 0.57 & 0.15 \\
\hline $\mathrm{CD}(\mathrm{p} \leq 0.05)$ & 0.15 & 0.15 & 0.15 & 0.86 & 0.38 & 1.68 & 0.44 \\
\hline
\end{tabular}

NS = Non significant, $\mathrm{S}=$ Sowing date, $\mathrm{F}=$ fertility level 
Table.2 Effect of dates of sowing and fertility levels on yield of baby corn

\begin{tabular}{|c|c|c|c|}
\hline \multirow[t]{2}{*}{$\begin{array}{l}\text { Treatments } \\
\text { MAIN PLOT }\end{array}$} & \multicolumn{2}{|c|}{$\begin{array}{l}\text { Baby corn yield } \\
\qquad\left(q \text { ha }^{-1}\right)\end{array}$} & \multirow[t]{2}{*}{$\begin{array}{l}\text { Green fodder } \\
\text { yield }\left(\mathbf{q ~ h a}^{-1}\right)\end{array}$} \\
\hline & $\begin{array}{l}\text { With } \\
\text { husk }\end{array}$ & $\begin{array}{l}\text { Without } \\
\text { husk }\end{array}$ & \\
\hline \multicolumn{4}{|l|}{ Dates of sowing } \\
\hline $18^{\text {th }}$ SMW & 69.73 & 19.88 & 358.01 \\
\hline $21^{\text {st }} \mathrm{SMW}$ & 63.83 & 18.47 & 341.02 \\
\hline $24^{\text {th }}$ SMW & 57.56 & 15.63 & 324.04 \\
\hline $27^{\text {th }} \mathrm{SMW}$ & 48.60 & 14.50 & 298.69 \\
\hline SEm \pm & 1.67 & 0.45 & 5.97 \\
\hline $\mathrm{CD}(\mathrm{p} \leq \mathbf{0 . 0 5})$ & 5.77 & 1.31 & 15.11 \\
\hline \multicolumn{4}{|l|}{ SUB PLOT } \\
\hline \multicolumn{4}{|l|}{$\begin{array}{l}\text { Fertility levels } \\
\left(\mathrm{N}: \mathrm{P}_{2} \mathrm{O}_{5}: \mathrm{K}_{2} \mathrm{O} \mathrm{kg} \mathrm{ha}^{-1}\right)\end{array}$} \\
\hline $\begin{array}{l}\text { Unfertilized control } \\
\left(\mathbf{F}_{0}\right)\end{array}$ & 41.11 & 11.32 & 292.51 \\
\hline $100: 50: 25 \quad\left(F_{1}\right)$ & 53.05 & 15.63 & 323.58 \\
\hline 120:60:30 & 68.89 & 19.83 & 343.13 \\
\hline 140:70:35 & 76.69 & 21.70 & 362.53 \\
\hline SEm \pm & 1.85 & 0.62 & 6.37 \\
\hline $\mathrm{CD}(\mathrm{p} \leq 0.05)$ & 5.41 & 1.81 & 17.87 \\
\hline
\end{tabular}

$\mathrm{S}=$ Sowing date, $\mathrm{F}=$ fertility level

\section{Effect of fertility levels}

\section{Yield attributes}

Data presented in Table 2 revealed that fertility levels had a significant effect on number of baby corn per plant, baby corn girth with and without husk, baby corn length with and without husk and weight of single baby corn with and without husk. Among various fertility levels, $\mathrm{F}_{3}$ fertility level ((140:70:35 N: P2O5: $\mathrm{K} 2 \mathrm{O} \mathrm{kg} \mathrm{ha}^{-1}$ ) recorded significantly higher number of baby corn per plant (2.46), baby corn girth with husk $(4.57 \mathrm{~cm})$ and without husk $(2.93 \mathrm{~cm})$, baby corn length with husk (17.30 $\mathrm{cm})$ and without husk $(12.60 \mathrm{~cm})$ and weight of single baby corn with husk $(33.50 \mathrm{~g})$ and without husk (10.61 g) compared to other fertility levels. However, unfertilized control
$\left(\mathrm{F}_{0}\right)$ registered significantly lower values of all the yield attributes viz., number of baby corn per plant (1.72), baby corn girth with husk (2.95 $\mathrm{cm})$ and without husk $(1.89 \mathrm{~cm})$, baby corn length with husk $(12.41 \mathrm{~cm})$ and without husk $(7.09 \mathrm{~cm})$, and weight of single baby corn with husk $(23.88 \mathrm{~g})$ and without husk (7.28 g). The higher growth characters (plant height, LAI, dry matter) under $\mathrm{F}_{3}$ fertility level might have played a significant role in producing more photosynthates thereby producing higher yield attributes (baby corn length with and without husk, baby corn girth with and without husk and baby corn weight with and without husk). The sufficient availability of photosynthates under higher fertility levels also might have enhanced number of flowers and their fertilization resulting in higher number of baby corn per plant. These results are in conformity with the 
findings of Channabasavanna et al., (2002), Raja (2001) and Thakur et al., (1997).

\section{Yield}

Data presented in Table 2 indicated that baby corn yield and green fodder yield were significantly influenced by fertility levels and among various fertility levels, $\mathrm{F}_{3}$ fertility level (140:70:35 N: $\mathrm{P}_{2} \mathrm{O}_{5}: \mathrm{K}_{2} \mathrm{O} \mathrm{kg} \mathrm{ha}^{-1}$ ) recorded significantly higher baby corn yield with husk (76.69 $\left.\mathrm{qha}^{-1}\right)$ and without husk (21.70 $\left.\mathrm{qha}^{-1}\right)$ and green fodder yield (362.53 qha $\mathrm{qh}^{-1}$ whereas unfertilized control $\left(\mathrm{F}_{0}\right)$ recorded significantly lowest baby corn yield with husk (41.11 $\left.\mathrm{ha}^{-1}\right)$ and without husk (11.32 $\left.\mathrm{qha}^{-1}\right)$ and green fodder yield (292.51 $\left.\mathrm{qha}^{-1}\right)$ compared other fertility levels. The yield components viz., baby corn per plant, girth of baby corn with and without husk $(\mathrm{cm})$, baby corn length with and without husk $(\mathrm{cm})$ and baby corn weight with and without husk $(\mathrm{cm})$ increased significantly up to $\mathrm{F}_{3}$ fertility level thereby the combined effect of these components resulted in higher yield. The higher uptake of nutrients by the crop under higher fertility levels produced higher LAI meaning more production of photosynthates leading to higher dry matter production in terms of baby corn yield and green fodder yield. These results are in accordance with the results obtained by Singh (2001), Lambert et al., (1994) and Madhavi et al., (1995).

Summary and conclusion are as follows:

The experiment was conducted at Crop Research Farm of Division of Agronomy, Faculty of Agriculture, Sher-e-Kashmir University of Agricultural Sciences \& Technology of Kashmir, Wadura Sopore during Kharif, 2018 to study the "effect of dates of sowing and fertility levels on yield attributes and yield of baby corn (Zea mays L.) under temperate conditions".

The effect of sowing dates on the crop revealed that crop sown in $18^{\text {th }} \mathrm{SMW}\left(30^{\text {th }}\right.$ April $-6^{\text {th }}$ May) produced significantly higher yield attributes and yield compared to all other sowing dates. Fertility level 140:70:35 N: $\mathrm{P}_{2} \mathrm{O}_{5}$ : $\mathrm{K}_{2} \mathrm{O} \mathrm{kg} \mathrm{ha}{ }^{-1}\left(\mathrm{~F}_{3}\right)$ produced significantly higher yield attributes and yield than all other fertility levels.

In conclusion, the study revealed that baby corn sown in $18^{\text {th }}$ SMW (30 $0^{\text {th }}$ April $-6^{\text {th }}$ May) and applied with $\mathrm{F}_{3}$ fertility level (140:70:35 N: $\mathrm{P}_{2} \mathrm{O}_{5}: \quad \mathrm{K}_{2} \mathrm{O} \mathrm{kg} \mathrm{ha}^{-1}$ ) produced higher yield attributes and yield of baby corn. It is therefore advisable to be adopted by farmers producing baby corn under temperate conditions.

\section{References}

Anonymous, 2018. Statistical Digest (2018-19). Directorate of Economics and Statistics, Planning and Development, Government of Jammu and Kashmir, Srinagar, pp. 105-108.

Arash, F., M. E. Ghobadi and S. J. Honarmand (2011). The effect of water deficit and sowing date on yield components and seed sugar content of sweet corn. African Journal of Agricultural Research 6(26): 769-5774.

Channabasavanna, A.S., Biradar, D.P. and Yelemani, S.G. 2002. Effect of poultry manure and NPK on growth and yield of maize. Karnataka Journal of Agricultural Sciences, 15: 353-355.

Goalada, S. L., Sharma, G. L. and Jain, H. K. 2013. Performance of baby corn (Zea mays L.) as Influenced by spacing, nitrogen fertilization and plant growth regulators under sub humid conditions in Rajasthan, India. African Journal of Agricultural Research 8(12): 1100-1107.

Jaliya, M.M., Falaki, A.M., Mahmud, M. and Sani, Y.A. 2008. Effect of sowing date and NPK fertilizer rate on yield and yield components of quality protein maize (Zea mays L.). ARPN Journal of Agricultural and Biological Science 3(2): 23-29.

Kawatra and Seghal, 2007. Value added products of maize (Quality protein maize and baby corn). National Conference on "Double Maize production" organized by 
IFFCO foundation, ICAR,DMR, DAC \& IFFCL at New Delhi on May 08-09, 2007.

Khan, N., Qasim, M., Ahmed, F., Naz, F. and Khan, R. 2002. Effect of sowing dates on yield of maize under agroclimatic conditions of Kaghan valley. Asian Journal of Plant Sciences 1: 146-147.

Kumar A. and Thakur, K.S. 2004. Effect of integrated nutrient management on promising composite maize (Zea mays $\mathrm{L}$.) varieties under rainfed mid-hill conditions of Himachal Pradesh. Indian Journal of Agricultural Sciences 74(1) 40-42.

Lambert, K., Turgut, I. and Sorenson, I. B. 1994. Effect of plant population and NPK doses on fresh ear yield and yield components of sweet corn grown under Bursa condition. Turkish Journal of Agriculture and Forestry 24(3): 341-347.

Madhavi, B.L., Reddy, M.S. and Rao, P.C. 1995. Integrated nutrient management using poultry manure and fertilizers. Andhra Pradesh Agricultural University Research Journal 23: 1-14.

Mahmood, T., Saeed, M. and Ahmad, R. 1999. Water and potassium management for enhanced maize (Zea mays L.) productivity. International Journal of Agriculture Biology 1(4): 314-317.

Mahmood, T., Saeed, M. and Ahmad, R. 1999. Water and potassium management for enhanced maize (Zea mays L.) productivity. International Journal of Agriculture Biology 1(4): 314-317.

Mokhtarpour, H., Feyzbakhsh, M. T., Mossavat,
S. A. and Pourfarid, A. 2013. Effects of sowing dates and plant density on qualitative and quantitative yield of sweet corn forage in summer sowing. Asian Journal of Experimental Biological Sciences 4(2): 251-255.

Raja, V. 2001. Effect of nitrogen and plant population on yield and quality of super sweet corn (Zea mays saccharata). Indian Journal of Agronomy 46: 246-249.

Shirkhani, A. Ahmadi, G.H. Mohammadi, G. and Ghitouli, M. 2012. Effects of cropping architect and sowing date on forage quantity and quality of corn (Zea maize L.) as a second crop in Western Iran. Annals of Biological Research 3(9): 4307-4312.

Singh, S.D. 2001. Effect of irrigation regimes and nitrogen levels on growth, yield and quality of Baby corn (Zea mays L.), Madras Agricultural Journal 88: 371374.

Tamadon, R. M. 2000. Effects of sowing date and plant density, yield and yield components of sweet corn var. KSC403 su in Mazandaran conditions. M.Sc. Thesis of Agronomy, University of Mazandaran, Iran. P.104.

Thakur, D.R., Om Prakash, Kharwara, P.C. and Bhalla, S. K. 1997. Effect of nitrogen and plant spacing on growth, development and yield of baby corn (Zea mays L.). Indian Journal of Agronomy 42 (3): 479 483.

\section{How to cite this article:}

Tanveer Ahmad Ahngar, Zahida Rashid, Raies A. Bhat, A. A. Saad, M. Anwar Bhat, Taussef Ahmad Bhat, Suhail Inamullah, Shabeena Majid, Seerat Jan and Aijaz Nazir. 2020. Effect of Dates of Sowing and Fertility Levels on Yield Attributes and Yield of Baby Corn (Zea mays L.) under Temperate Conditions. Int.J.Curr.Microbiol.App.Sci. 9(08): 2728-2735. doi: https://doi.org/10.20546/ijcmas.2020.908.309 